\title{
ПРОБЛЕМА БІЖЕНЦІВ ПЕРШОЇ СВІТОВОЇ ВІЙНИ У ВЗАЕМИНАХ УКРАЇНСЬКОЇ ЦЕНТРАЛЬНОЇ РАДИ ТА ТИМЧАСОВОГО УРЯДУ РОСІї
}

\author{
Л. М. Жванко
}

\begin{abstract}
Жванко Л. М. Проблема біженців Першої світової війни у взаєминах Української Центральної Ради та Тимчасового уряду Росії. У статті, підготовленій на основі архівних документів та періодичних видань 1917 р., розкриваються взаємини Тимчасового уряду Росії та Української Центральної Ради у справі врегулювання проблеми біженців Першої світової війни. Наголошується на проблемах співпраці двох новостворених урядових структур, а також несприйняття українських гуманітрних ініціатив з боку російської влади. На жаль, протягом весни - осені 1917 р. так і не було досягнуто конструктивних рішень у справі подолання цієї гуманітарної проблеми, оскільки Тимчасовий уряд не сприймав владу Києва, як самостійного політичного гравця на постімперських теренах.
\end{abstract}

Ключові слова: Перша світова війна; біженці; Українська Центральна Рада; Тимчасовий уряд.

Жванко Л. Н. Проблема беженцев Первой мировой войны во взаимоотношениях Украинской Центральной Рады и Временного правительства. В статье, подготовленной на основе архивных документов и периодических изданий 1917 г., раскрываются взаимоотношения Временного правительства России и Украинской Центральной Рады в деле урегулирования проблемы беженцев Первой мировой войны. Внимание акцентируется на проблемах сотрудничества двух новых правительственных структур, а также неприятии украинских гуманитарных инициатив со стороны российских властей. К сожалению, на протяжении всего периода существования Временного правительства не было достигнуто конструктивных решений в деле урегулирования проблемы беженцев, поскольку Временное правительство не воспринимало власть Киева как самостоятельного политического игрока на постимперском пространстве.

Ключевые слова: Первая мировая война; беженцы; Украинская Центральная Рада; Временное правительство.

Zhvanko L. M. The Problem of Refugees of the World War I in Relations between the Ukrainian Central Rada and the Provisional Government of Russia. The February Revolution of 1917, which unfolded against the backdrop of the events of the World War I, destroyed the Romanovs' three-hundredyear-old empire and, as a result, made adjustments to the system of assistance to refugees. The problems of cooperation between the two newly formed government bodies and the non-acceptance of Ukrainian humanitarian initiatives by the Russian authorities are emphasized. Unfortunately, during the spring-autumn of 1917 no constructive decisions were made to overcome this humanitarian problem, since the Provisional Government did not perceive the power of Kyiv as an independent political player in the post-imperial territories.

Keywords: World War I; refugees; Ukrainian Central Rada; Provisional Government.

Лютнева революція 1917 р., яка відбувалася на тлі подій Першої світової війни, знищила трьохсотлітню імперію Романових, а відтак внесла свої корективи й у систему допомоги біженцям. Ця категорія людності стала чи не найвразливішою в умовах трансформаційних процесів, що розгорталися на теренах колишньої Російської держави. У цих умовах біженці продовжували перебувати в імперському правовому полі, однак дія відцентрових факторів, привели до появи на руїнах імперії нових державних утворень, за певних умов спонукала останніх зайнятися розробкою власних нормативно-правових засад та творення під них відповідних структур. Наскільки дієвою та результативною була співпраця нового українського уряду з Тичасовим урядом Росії у царині соціальної опіки біженців, буде розглянуто у запропонованому дослідженні.

На початку березня 1917 р. на українських землях владу на себе взяла Українська Центральна Рада (далі - УЦР), ставши з перших днів свого існування «... об’єднуючим, координуючим і направляючим центром, до якого звідусіль, не тільки з України, а й з інших близьких і далеких країв, потягнулося пробуджене могутнім національно-визвольним 
зривом українство» ${ }^{1}$. УЦР, відповідно до положень I Універсалу, оприлюдненого 10 червня 1917 р., зобов'язувалася «... бути на чолі нашого народу, стояти за його права і творити новий лад вільної АВТОНОМНОЇ УКРАЇНИ»². Слід відзначити, що в цей бурхливий час у свідомості українських біженців, тимчасово розселених у тилових російських губерніях, з'явилося переконання, що саме Українська Центральна Рада є «... завзятим борцем за національні права України» ${ }^{3}$.

На час приходу до влади УЦР в українських губерніях перебувала значна кількість біженців. Дані табл. 1 з різних причин не можуть бути вичерпними, проте й вони вказують на загальну тенденцію до збільшення їх кількості. Біженську масу слід розглядати як мінливий організм, який перебував у перманентному русі, що досить ускладнювало збір статистичних даних. Загальним чинником, який в умовах розгортання революційних подій підштовхнув біженців на зрушення з місць тимчасового проживання, було усвідомлення ними факту стрімкого закінчення війни. Відтак з'явилася надія на можливість якнайшвидше повернутися додому. Водночас наростання суспільного хаосу та непевність у завтрашньому дні теж спонукали цих людей до самочинного переміщення в межах колишньої Російської імперії.

Таблиця 1

Кількість біженців в українських губерніях (Літо - осінь 1917 р.)

\begin{tabular}{|c|c|c|c|}
\hline $\begin{array}{l}\text { № } \\
\Pi / \Pi\end{array}$ & Губернія & $\begin{array}{c}\text { Дані МВС } \\
\text { Тимчасового уряду (червень) }\end{array}$ & $\begin{array}{c}\text { Дані Губернських нарад } \\
\text { у справах біженців }\end{array}$ \\
\hline 1. & Волинська & 238553 & 305613 (серпень) \\
\hline 2. & Катеринославська & 234700 & 241671 (серпень) \\
\hline 3. & Київська & 59687 & 59687 \\
\hline 4. & Подільська & 9115 & 9115 \\
\hline 5. & Полтавська & 48551 & 56540 \\
\hline 6. & Таврійська & 47508 & 47508 \\
\hline 7. & Харківська & 126915 & 95774 (без Харкова) \\
\hline 8. & Херсонська & 46590 & 24796 (березень) \\
\hline \multirow[t]{2}{*}{9.} & Чернігівська & 37910 & 39106 (серпень) \\
\hline & Усього & 849523 & 879810 \\
\hline
\end{tabular}

ЦДАВО України. Ф. 799, Оп. 1, Спр. 12, Арк. 2; Спр. 13, Арк. 3; Спр. 6, Арк. 12; Спр. 14, Арк. 3; Спр. 27. Арк. 30

Збільшення кількості біженців саме на українських землях відбувалося під впливом кількох факторів. Перш за все Україну необхідно розглядати як транзитну територію, якою тисячі поляків, латишів, литовців та представників інших етносів розпочали свій рух із охопленої революційною анархією Росії. Однак більшість із них не мали засобів до існування, а тому тимчасово осідали в українському прикордонні - Чернігівській і Харківській губерніях. 3 наростанням продовольчої кризи іноземні біженці також намагалися потрапити до України. Іншу групу прибульців склали біженці-українці, які хотіли якомога скоріше повернутися в Україну з «неврожайних російських губерній», де вони були розселені 3 початку евакуації. Фактично ці люди й надалі перебували у статусі біженців, оскільки, втративши за роки війни своє майно та житло, цілком залежали від українських інституцій, на яких покладалися повноваження у галузі опіки біженців.

Нова українська влада, безумовно, мала стати оборонцем інтересів біженців, проблеми яких скласти комплекс проблем. Важливим моментом в нових умовах став органічно поєднаний процес творення української нормативно-правової бази та системи відповідних органів, здатних реалізувати державну політику в окресленій царині. Принципово 
важливим є твердження щодо еволюції діяльності відповідних українських структур - від перебування у фарватері російської системи допомоги біженцям та пошуків взаємодії $з$ цього питання з Тимчасовим урядом до формування власного правового поля, постановки проблеми біженців на перемовинах у Брест-Литовську, започаткування широкої підготовчої роботи до організації реевакуації біженців. Доба Української Центральної Ради $\epsilon$ перехідною в організації соціального захисту біженців від системи, закладеної в часи Російської імперії, до власне української, створити яку прагнула Українська Народна Республіка (далі - УНР). Завершити цей процес вдалося уже в часи Гетьманату П. Скоропадського. Зрозуміло, що урядовим структурам УЦР було надзвичайно важко в тогочасних умовах творити власну вертикаль органів для допомоги біженцям, реалізувати свої плани в означеній царині ${ }^{4}$.

Перш за все, слід звернути увагу на ту політичну ситуацію, в якій перебувала новостворена УЦР, оскільки на весну 1917 р. Україна фактично перебувала у стані війни 3 державами Четверного союзу. Ї̈̈ територією - Волинською і Подільською губерніями проходила лінія Південно-Західного фронту. Відтак протягом 1917 р. в Україні у зв'язку з постійною зміною політичної ситуації, а відтак і самого ії̈ державного статусу, трансформувалися і підходи до розробки засад політики у царині біженства під впливом еволюції взаємодії з правлячими колами нової Росії. Відтак можна виокремити два невеликі в часовому просторі періоди. На першому, який тривав протягом березня - середина літа 1917 p., керівництво справами біженства в Україні продовжувала здійснювати Особлива нарада 3 улаштування біженців (далі - ОН з УБ), яка діяла у структурі Міністерства внутрішніх справ Тимчасового уряду Росії і вся біженецька складова існувала в його правовому полі. У той час Українська Центральна Рада послідовно підтримувала урядовий курс і розраховувала на позитивне ставлення до ідеї української автономії. Відповідно уся біженська складова в Україні продовжувала функціонувати в загальноросійській системі координат.

Тимчасовий уряд, у структурі Міністерства внутрішніх справ продовжувала працювати створена у 1915 р. Особлива нарада з улаштування біженців, став виразником політики у сфері соціального захисту біженців на теренах колишньої імперії. Оновлений склад інституції очолив член Державної Ради В. Енгельгардт ${ }^{5}$. Серед головних завдань нова російська влада визнала за необхідне демократизувати діяльність організацій, які займалися допомогою біженцям, в умовах широкого залучення до їх роботи самих біженців, ліквідувати благодійні установи, фундаторами яких свого часу виступили члени царської родини, унормувати допомогу біженцям та ін. Згідно із завданнями передбачалося оптимізувати й саму систему допомоги біженцям. Перш за все Всеросійський земський союз, лідер якого князь Г. Львов став очільником Тимчасового уряду. I вже 11 березня 1917 р. Г. Львов, обговорюючи з В. Енгельгардом нагальні проблеми біженства, наголосив на необхідності об'єднання всіх організацій, які займалися справами біженців, передавши керівні важелі саме Земському союзу 6 . Керівник уряду був схильний до думки, що таким органом може стати саме Земський Союз, який чимало зробив у справі соціального захисту біженців. Принципово важливим моментом стало визнання того, що справа соціального захисту біженців за нових реалій життя мала здійснюватися на громадських засадах із залученням до цього широкого кола біженців. При цьому передбачалося утворити нову посаду - комісар у справах біженців, який на рівні держави мав координувати свю складову жопомоги біженцям ${ }^{7}$.

Українська Центральна Рада долучилася до розв'язання біженецьких проблем уже після створення 15 червня 1917 р. Генерального секретаріату ${ }^{8}$. Його головою з одночасним виконанням повноважень генерального секретаря внутрішніх став В. Винниченко, один iз найвпливовіших тогочасних діячів українського руху, а заступником був призначений П. Понятенко (1878-1971) - громадсько-політичний діяч, журналіст, письменник, родом 3 Полтави. П. Понятенко, враховуючи, що В. Винниченко виконував насамперед обов'язки голови Секретаріату, в основному здійснював керівництво Секретарством внутрішніх справ ${ }^{9}$ та «опікувався справами біженців із Галичини і Буковини, українськими громадянами, що залишилися в Росії і не могли повернутися в Україну» ${ }^{10}$. Також у його компетенції, певно, перебували й справи утвореного у структурі секретарства внутрішніх справ, «біженецько-плінницького відділу» (в інших документах - відділу біженців, полонених і виселенців $)^{11}$. Керував роботою відділу К. Лоський (1874-1933) - історик права, укра- 
їнський громадсько-політичний діяч, дипломат. Можна стверджувати, що П. Понятенко і К. Лоський стали першими в новітній історії України урядовцями, які взяли на себе повноваження щодо організації допомоги біженцям Першої світової війни.

Ще однією інституцією, яку було започатковано 19 червня 1917 р. у Києві, стала Окружна нарада у справах біженців - представницька структура, чия компетенція поширювалася на Волинську, Київську, Подільську, Полтавську і Чернігівську губернії. Ініціатором iii створення виступив «головуповноважений по біженцях Південно-Західного фронту» I. Стерлигов ${ }^{12}$. Зі складу наради було виокремлено виконавчий комітет: А. Ржепецький, голова Київської губернської наради у справах біженців; І. Стерлигов, головуповноважений у справах біженців; представники УЦР, місцевого земства, Київського губернського продовольчого комітету, штабу Київського військового округу, Всеросійського земського союзу (далі - ВЗС) та Всеросійського союзу міст (далі - ВСМ). 3 утворенням Окружної наради стає очевидним формування в Україні двох центрів з вирішення проблем біженців - у Генеральному секретаріаті та при головуповноваженому Південно-Західного фронту. При цьому останній, що було досить важливо, мав реальні фінансові важелі впливу. І хоча до складу Окружної наради ввійшли представники УЦР, перебіг подальших подій показав, що українська влада всіляко намагалася обмежити її вплив та і взагалі скасувати. Головним же завданням інституції стала розробка плану повернення додому біженців та його практична реалізація ${ }^{13}$.

Таким чином, на першому етапі діяльність УЦР у царині біженства була скоріше фрагментарною і виражалася у створенні окремого відділу при Генеральному секретарстві внутрішніх справ. Така ситуація $є$ цілком природною, оскільки керманичі українського руху бачили автономну Україну у складі демократичної Росії, в якій вже існувала відповідна вертикаль. 3 іншого боку перехід УЦР в опозицію до Тимчасового уряду після оприлюднення 10 (23) червня 1917 р. Першого Універсалу та створення Генерального секретаріату означали, серед іншого, і зміну ії ставлення до проблеми біженства. Небажання Тимчасового уряду Росії визнавати правомірність Генерального Секретаріату, а відтак i його структур, які опікувалися проблемами біженців, призвело до балансування між ними місцевих біженецьких органів, що, у свою чергу, породжувало різні непорозуміння, зволікання, головним чином, у фінансовому плані. Зрозуміло, що така ситуація тільки підсилювала напруження серед біженців, які на той час уже розпочали самостійне некероване «дрейфування» у бік західних кордонів України.

Другий період взаємин між УЦР і Тимчасовим урядом у царині біженства Першої світової війни тривав від середини літа і до моменту більшовицького перевороту в жовтні 1917 р. Він характеризувався еволюцією біженських структур УЦР, iї спробами порозумітися з Міністерством внутрішніх справ Тимчасового уряду, розробкою проектів основоположних документів у галузі біженства. При цьому слід наголосити, що в останні місяці існування Тимчасового уряду в його стосунках із УЦР зберігалася невизначеність ${ }^{14}$, яка очевидно й підштовхнула українську сторону до самостійних пошуків оптимальних шляхів розв'язання біженецьких проблем та формування відповідної вертикалі.

3 другої половини літа 1917 р. в Україні можна спостерігати спроби створення українських біженецьких структур різного підпорядкування. Так, у другій половині липня 1917 р. товариш генерального секретаря внутрішніх справ П. Понятенко звернувся до командування Південно-Західного фронту із проханням дозволити Українській Центральній Раді створити на фронті інститут комісарів у справах біженців. Доцільність такої посади визначалася необхідністю планомірного розв'язання проблем біженців. 25 липня генерал О. Лукомський, начальник штабу Верховного Головнокомандуючого, у телеграмі-відповіді зазначив, що на Південно-Західний фронт, згідно з наказом МВС Тимчасового уряду, прибув головуповноважений у справах біженців «досвідчений у цій справі» I. Стерлигов. Українським комісарам, у разі згоди УЦР, надавався статус помічників, безпосередньо підпорядкованих цьому головуповноваженому도. I вже 26 липня 1917 р. було введено інститут «комісарів виселенсько-біженецько-плінницьких справ». 28 липня постановою УЦР про затвердження бюджету Генерального секретарства внутрішніх справ було виділено по 500 крб. на їхню щомісячну заробітну плату ${ }^{16}$.

1 серпня 1917 р. у Києві відбулося засідання Окружної наради у справах біженців. Головуючий А. Ржепецький поставив питання щодо необхідності виділення зі складу ви- 
конавчого комітету робочої президії, яка б мала виконувати покладені на нараду функції. Проте представник УЦР висловився за недоцільність такого кроку, оскільки із затвердженням Тимчасовим урядом «Положення про Генеральний секретаріат», саме Центральна Рада була зобов'язана взяти на себе управління діяльністю Окружної наради. Фактично можна говорити про прагнення УЦР підпорядкувати та зосередити в своїх руках керівні важелі у справі біженства. Пропозицію розкритикував I. Стерлигов, позаяк «... справа (біженців - Л. Ж.) настільки спішна, що чекати доки уряд затвердить «Положення про Генеральний секретаріат» неможна, необхідно президію утворити негайно» ${ }^{17}$. Члени зібрання, не дійшовши згоди щодо створення керівних підрозділів Окружної наради, вирішили відкласти розгляд цього питання до наступного засідання.

У другій половині літа 1917 р. одночасно з процесом становлення Окружної наради фахівці біженецько-плінницького відділу під керівництвом К. Лоського розробили «Проект Тимчасових правил з управління справами допомоги біженцям в Україні», який фактично став першим законодавчим актом української влади у царині біженства ${ }^{18}$. Необхідно зазначити, що остаточно цей дещо скоригований відповідно до нових політичних умов документ, набув свого юридичного оформлення 28 грудня 1917 р. у вигляді Постанови Української Центральної Ради про затвердження «Тимчасових правил управління справами допомоги біженцям на території України» ${ }^{19}$.

Одинадцять статей «Проекту» в стислому вигляді визначили основи політики УЦР у питанні соціального захисту біженців Першої світової війни, владну вертикаль, фінансові засади та інші аспекти перш за все у межах п'яти українських губерній. Зокрема, було підтверджено, що «усіма справами допомоги біженцям в Україні відає Генеральне Секретарство внутрішніх справ» (ст. 1). Для безпосереднього керівництва окресленим напрямом внутрішньої політики при Генеральному секретарстві внутрішніх справ передбачалося утворити «...особливий Тимчасовий Біженецький відділ, який складається 3 Директора i канцелярії при ньому з особливим штатом» (ст. 2).

Усе діловодство у справах біженців на рівні Генерального секретарства внутрішніх справ та рівноцінних інституцій провадилося «... за підписом директора відділу і скріпленого діловодом, а зносини 3 вищими інституціями за підписом Генерального Секретаря внутрішніх справ або його товариша зі скріпленням директора відділу» (ст. 3). Для розв'язання справ допомоги біженцям при Генеральному секретарстві внутрішніх справ передбачалося утворити представницький колегіальний орган - «Особливу нараду зі справ біженецьких». Ї̈̈ роботою мав керувати товариш Генерального секретаря внутрішніх справ чи директор біженецького відділу (ст. 6-7) ${ }^{20}$. Склад інституції передбачалося сформувати з трьох представників Генерального секретарства внутрішніх справ, головуповноваженого з улаштування біженців Південно-Західного фронту, по два представників від кожної $з$ п'яти губернських нарад у справах біженців і центральних біженських організацій (причому один із цих двох представників обов'язково мав бути із біженецького середовища), по одному представнику від Генерального військового штабу, від ВЗС, ВСМ, Київської ради солдатських і робітничих депутатів, управління Києво-Воронезької залізниці, Київського губернського продовольчого комітету, управління Південно-Західних залізниць, Київського управління водних шляхів, Штабу Київського військового округу і управління головного начальника постачання Південно-Західного фронту ${ }^{21}$. Фактично до складу наради передбачалося ввести значну кількість представників різних державних, громадських, військових інституцій. Для більш дієвого ії функціонування було висловлено припущення щодо можливості виділення з її складу Виконавчого комітету.

Важливим моментом, що принципово мав позначитися на результативності біженецької політики, було налагодження своєчасного і належного фінансування. Розпорядником коштів, отриманих з кількох джерел - від ОН з УБ МВС Тимчасового Уряду, від «... відділу постачання Південно-Західного фронту та від інших структур на допомогу біженцям, які проживають у межах 5 губерній» - визнавалося лише Генеральне секретарство внутрішніх справ. До того ж «усі організації у справах біженців» були позбавлені права «... отримувати кошти з Петрограду без відома Генерального Секретаріату УЦР» ${ }^{22}$.

Одним із пріоритетних напрямків політики Генерального секретаріату внутрішніх справ стало й надання фінансової підтримки інституціям, які поза межами України надавали допомогу біженцям-українцям, а також уродженцям з Холмщини і Буковини. Тим са- 
мим можна стверджувати, що українська влада зосередила свою увагу на усіх без винятку біженцях, не зважаючи на їх етнічну, соціальну, конфесійну приналежність та географію перебування. Захисником інтересів українських біженців у Росії виступив П. Стебницький, громадський і політичний діяч, письменник і публіцист, який на той час проживав у Петрограді і якого українська громада Петрограда висунула на посаду представника Української Центральної ради при Тимчасовому уряді.

У прикінцевих положеннях «Проекту Тимчасових правил з управління справами допомоги біженцям в Україні» зазначалося, що у разі затвердження даного документа, «... скасовується Київська окружна нарада у справах біженців, всі грошові ресурси цієї установи передаються до біженецького відділу Генерального секретарства внутрішніх справ» ${ }^{23} .21$ вересня 1917 р. В. Винниченко направив на затвердження М. Авксентьєву, міністру внутрішніх справ Тимчасового уряду, «Проект Тимчасових правил з управління справами допомоги біженцям в Україні» та «Записку про організацію справи допомоги біженцям на Україні» ${ }^{24}$. У супровідному листі генеральний секретар внутрішніх справ висловив прохання: «... утвердити цей проект найближчим часом з огляду на необхідність якнайшвидшого упорядкування справ біженців на Україні і підготовки плану повернення біженців на батьківщину і асигнувати у розпорядження генерального секретарства внутрішніх справ на перший час аванс 500 тис. крб. на організацію справи допомоги біженцям і субсидіювання біженецьких організацій» ${ }^{25}$. У цьому листі вперше було офіційно викладено думку щодо необхідності розробки плану реевакуації біженців з України до своїх домівок.

У «Записці про організацію справи допомоги біженцям на Україні» В. Винниченко, пояснюючи ситуацію, в якій перебувала справа надання допомоги біженцям, наголосив на невідповідності «Керівних положень з улаштування біженців», прийнятих 2 березня 1916 р., «... сьогочасному пореволюційному ходу речей» ${ }^{26}$. Новизна політичної ситуації проявилася і в нездатності єдиного центру, зосередженого у Петрограді, «... слідкувати за [біженецькими] справами у всій державі» ${ }^{27}$. Така ситуація, на думку В. Винниченка, призвела до фінансової плутанини, оскільки кошти для українських установ і організацій надходили з різних джерел. Багато в чому була розрізненою і їхня діяльність. Тому на порядок денний в Україні вийшло питання створення спеціальної інституції, у компетенції якої перебували, по-перше, керівництво фінансовими аспектами справи, по-друге, здійснення систематичних заходів у справі допомоги біженцям, по-третє, розробка плану повернення їх до своїх домівок. I, нарешті, український урядовець підтвердив бажання Генерального секретарства внутрішніх справ узяти на себе опікування виселенцями та військовополоненими ${ }^{28}$.

Для з'ясування ситуації, пов'язаної із прагненням української влади створити власну структуру, у компетенції б якої перебувала справа соціального захисту біженців, до Києва був направлений В. Богуцький, товариш міністра внутрішніх справ Тимчасового уряду, який до середини літа 1917 р. обіймав посаду заступника міського голови Одеси ${ }^{29}$. Крім того, В. Богуцькому було доручено провести «... об’їзд біженських районів з метою об'єднання заходів щодо влаштування біженців» ${ }^{30}$. Серед українських міст, крім Києва, уповноважений Тимчасовго уряду відвідав Одесу. В. Богуцький, ознайомившись із «Проектом Тимчасових правил з управління справами допомоги біженцям в Україні», заявив що останній іде в розріз з існуючими в Росії законами, а відтак вимагав часу на розгляд $\mathrm{i}$ вивчення. Натомість він запропонував тимчасово до затвердження проекту створити при Генеральному секретарстві внутрішніх справ Краєву нараду у справах біженців (далі КН у СБ), яка б об'єднала «... усі структури України, які займаються справами біженців» ${ }^{31}$. Основоположним принципом її функціонування мала стати узгодженість дій із рішеннями ОН з УБ МВС Росії, тим самим за останньою визнавалося керівництво біженецькою складовою на всьому просторі, де поширювалася юрисдикція Тимчасового уряду.

Наступним кроком до створення української інституції у справах біженців можна назвати засідання Київської окружної наради з питань біженців 28 вересня 1917 р., на якому представники УЦР порушили цю проблему. На Київську нараду прибули представники військового командування та української влади, громадських і етнічних комітетів, які після повалення Російської імперії проводили свою діяльність на українських теренах. Від Генерального секретарства внутрішніх справ на нараді працювали I. Красковський і 
К. Лоський. В. Богуцький, який був запрошений на нараду, своїм виступом намагався зосередити увагу на кількох важливих, на думку Тимчасового уряду, моментах. Перш за все, і це вже в котре, було наголошено на необхідності реорганізувати структури соціального захисту біженців на демократичних засадах. Хоча на той час до складу місцевих комітетів вже було введено представників біженців, як запоруку демократичності у прийнятті рішень. В. Богуцький також наголосив необхідності задоволення культурно- просвітніх потреб біженців, на його думку, як найневідкладніших ${ }^{32}$. I нарешті, за умов скорого закінчення війни, на його думку, належало обговорити проблему евакуації біженців. Натомість українські виступаючі, у свою чергу, на порядок денний поставили дещо інші проблеми. Для представників УЦР було важливим, щоб саме Рада як крайовий орган влади, стала центром, навколо якого й гуртувалася б робота у справах біженців. На цьому й наголосив у виступі І. Красковський, озвучуючи ідею створення самостійної структури у справах біженців з відповідною правовою базою. Його підтримав представник ВЗС Гольдеман. Нова інституція поряд із з утвореним у червні 1917 р. біженецько-плінницьким відділом, мала стати широким представницьким органом, на яку покладалася розробка програмних засад політики України у царині біженства. У свою чергу процес створення національного органу у справах біженців просувався складно, наражаючись на протидію Тимчасового уряду Росії, його небажання співпрацювати з українською владою.

Знаковою для розбудови справи біженства в Україні стала нарада, скликана 5 жовтня 1917 р. за ініціативи генерального секретаря внутрішніх справ. На неї прибули представники влади, громадських спілок допомоги біженцям, етнічних комітетів, місцевих самоврядувань - М. Вітерова (Київський комітет українців-галичан і буковинців, постраждалих від війни), О. Марченко (представник головуповноваженого Південно-Західного фронту), А. Ржепецький (Київська ГН з УБ), Е. Реттингер Е., С. Москалевський (Центральний обивательский комітет), С. Грінберг, Б. Вайншельбаум (Сврейський комітет), О. Свєчин (голова Чернігівської губернської земської управи), Сосай, Давидюк, П. Малончук, Шкетін (Рада делегатів організацій біженців Києва), П. Слатов (Рада робітників і солдатських депутатів Києва), М. Козловський (управляючий конторою Київського відділу Всеросійського комітету біженців), К. Катлап (Латиський комітет з надання допомоги біженцям), М. Юшкевич (Київська обласна рада Польського товариства допомоги жертвам війни), 3. Мірна (Українське товариство «Південь Росії»), П. Мокроус і С. Блавацький (Комітет допомоги українським виселенцям при Центральній Раді), А. В’язлов (Волинський губернський комісар), Я. Корпачів (Летичівський повітовий комісар, представник Подільського губернського комісара), М. Ясько (Полтавське губернське земство), Кандиба (Волинське губернське земство), Д. Дорошенко (крайовий комісар Галичини і Буковини), Даймидович (Київський відділ Литовського товариства допомоги постраждалим від війни), В. Гаспар'ян (BCM), Є. Португалов (управління справами Галицько-Буковинського комітету), А. Зарембський (голова Волинського губернського земства) та ін. ${ }^{33}$.

Перш за все на засіданні було обговорено та ухвалено поданий директором біженецького відділу К. Лоським «Проект Тимчасових правил з управління справами допомоги біженцям в Україні». При цьому вже було змінено назву інституції з «Особливої наради зі справ біженецьких» на «Крайову нараду у справах біженців», як-то запропонував В. Богуцький. Також було вирішено, що саме Крайова нарада буде остаточно затверджувати кошториси губернських нарад у справах біженців

Ключовою тезою обговорення стало питання фінансової незалежності майбутньої структури - Крайової наради у справах біженців від ОН з УБ Тимчасового уряду як запоруки самостійної результативної діяльності. На цьому наголошували представники єврейського комітету С. Грінберг та Б. Вайншельбаум. Натомість I. Красковський висловився за «принцип концентрації допомоги біженцям на місцях - у Києві», позаяк Генеральний секретаріат і $є$ крайовою владою в Україні ${ }^{34}$. Жваву дискусію викликало питання щодо національного та біженського представництва в КН у СБ. Для остаточного визначення складу представництва в майбутній нараді було обрано під головуванням К. Лоського спеціальну комісію у складі Б. Вайншельбаума, М. Вітерової, С. Сосая, М. Козловського, С. Москалевського, М. Юшкевича, П. Мокроуса та А. Ржепецького. Після тривалих дебатів було ухвалено положення, що Крайова нарада у справах біженців при Генеральному секретарстві внутрішніх справ уповноважена отримувати від Державної скарбниці кошти 
і асигнувати з відповідними кошторисами місцевим біженецьким організаціям. На неї покладалося і затвердження обрахунків губернських нарад у справах біженців, які діяли в українських губерніях з 1915 р. як місцеві ланки ОН з УБ МВС $^{35}$.

Зрозуміло, що такі «самостійницькі» задуми УЦР у справі біженства зустріли опір Тимчасового уряду. Тому вже 7 жовтня 1917 р. до Києва знову прибув В. Богуцький для проведення наради з біженецьких питань. Його завданням було переконати українську владу у недоцільності створення незалежної біженецької структури, якою мала стати Крайова нарада у справах біженців, оскільки остання могла ухилятися від виконання рішень ОН з УБ. Він поставив під сумнів і «Проект Тимчасових правил з управління справами допомоги біженцям в Україні», оскільки до складу ОН з УБ «входять представники національних і громадських організацій, а також передбачається представник від Генерального секретарства» ${ }^{36}$. Фактично В. Богуцький озвучив ставлення Тимчасового уряду до українських потуг у царині розбудови системи біженецьких органів і дав зрозуміти, що надісланий В. Винниченком проект, можливо, й буде ухвалений, але за обов'язкового доопрацювання українською стороною ${ }^{37}$. Високопосадовець зауважив про відсутність у «Тимчасовій інструкції Генеральному Секретаріатові Тимчасового уряду на Україні» від 4 серпня 1917 р. будь-яких положень щодо біженців ${ }^{38}$, тому можна говорити про зволікання та небажання російського уряду підтримувати УЦР у розв'язанні проблем біженців.

Генеральний писар Генерального Секретаріату України О. Лотоцький, заперечуючи російському представнику, наголосив, що проект «Тимчасових правил» і $€$ проектом нового закону, покликаного виправити недоліки існуючого (від 30 серпня 1915 р. - Л. Ж.) як надто вже невідповідного сучасному моменту» ${ }^{39}$. В решті-решт В. Богуцький, виступаючи від імені Тимчасового уряду, погодився на утворення української біженецької структури, але без наділення iї фінансовими повноваженнями. Ззаначена нарада відбувалася у гострій дискусії, оскільки зіткнулися інтереси Тимчасового уряду, який не бажав мати в Україні самостійну і фінансово незалежну біженецьку структуру, натомість представники УЦР наполягали на іншому. До того ж вони виступили проти продовження роботи Окружної наради у справах біженців, яку, як своє дітище, відстоював А. Ржепецький ${ }^{40}$. Проти останньої також виступав і В. Богуцький, назвавши нараду «самочинною» і такою, що не розуміє своїх завдань ${ }^{41}$. Отже, нарада показала різне бачення у вирішенні проблеми біженців в Україні з боку Тимчасового уряду та Генерального секретаріату УЦР.

14 жовтня 1917 р. В. Винниченко направив ще одного листа О. Нікітіну, новому міністру внутрішніх справ Тимчасового уряду, в якому висловив прохання: «Беручи до уваги скрутне становище біженців в Україні, прохаю вас до затвердження Проекту Тимчасових правил з управління справами допомоги біженцям в Україні, дозволити утворити при генеральному секретарстві внутрішніх справ Крайову нараду у справах біженців, по типу, запропонованому Богуцьким $)^{42}$. Проте запити української сторони в умовах наростаючої чергової політичної кризи в Росії залишилися без відповіді, змушуючи іiі надалі самостійно вирішувати питання щодо формування своєї вертикалі біженських органів. Проте події, що розгорнулися в Україні та Росії з другої половини осені 1917 р., показали, що Центральна Рада стала в Україні правонаступницею скинутого Тимчасового уряду, маючи повне право на ведення самостійної політики у царині біженства та створення відповідної владної вертикалі. Фактично жовтневі події у Петрограді докорінно змінили ситуацію в Україні і підвели ії очільників до усвідомлення необхідності у стислі терміни створити повноцінну державу43.

Таким чином, взаємини Тимчасового уряду Росії та Української Центральної Ради в особі її Генерального Секретаріату засвідчили про небажання з боку московського владного центру визнати правомірність українського візаві у справі вирішення проблеми біженців Першої світової війни. У практичній площині це призвело до балансування між ними місцевих органів соціального захисту біженців, які діяли на українських теренах. Карколомні події осені 1917 р. аж ніяк не сприяли розв'язанню проблем біженців, а скоріше спричинили повну руйнацію існуючої системи допомоги цим людям. Російська держава після більшовицького перевороту фактично припинила існувати як цілісний організм, розпавшись на окремі державні та регіональні утворення. Українська влада залишилася сам на сам із сотнями тисяч біженців - жертв Першої світової війни. 
${ }^{1}$ Гошуляк I. Проблема територіальної соборності України в період діяльності Центральної Ради (до кінця 1917 р.) // Україна в революційних процесах перших десятиліть ХХ століття: міжнарод. наук.-теорет. конф. Київ, 2008. С. 131-132.

2 Універсал Української Центральної Ради до українського народу, на Україні й поза Україною сущого // Вісті з Української Центральної Ради. 1917. Травень (май). № 9.

3 Українській Центральній Раді, евакуйованих біженців Холмської губернії в Станиці Каменській Донської Области заява // Вісті з Української Центральної Ради. 1917. Травень (май). № 6.

${ }^{4}$ Жванко Л. Українська Центральна Рада і біженці Першої світової війни // Київська старовина. 2009. № 4. C. 49.

${ }^{5}$ Совещание по устройству беженцев // Приложение к «Известиям Херсонского Уездного Земства». 1917. № 14. 7 апреля. С. 32.

${ }^{6}$ Комиссар по делам беженцев // Бюллетень Комитета Юго-Западного фронта. 1917. 9-16 апреля.

${ }^{7}$ Совещание по устройству беженцев // Приложение к «Известиям Херсонского Уездного Земства». 1917. № 14. 7 апреля. С. 32.

${ }^{8}$ Довбня В. А., Дурнов С. С., Калюк О. М. Органи внутрішніх справ УНР часів Української Центральної Ради: організаційно-правові засади діяльності. Дніпропетровськ: IMА-прес, 2008. С. 10.

${ }^{9}$ Кудлай О. Б. Діяльність Народного міністерства внутрішніх справ УНР. // Український історичний журнал. 2005. № 2. С. 91.

${ }^{10}$ Верстюк В. Ф., Осташко Т. С. Діячі Української Центральної Ради: бібліографічний довідник. Київ [б. в.], 1998. С. 147.

${ }^{11}$ Кудлай О. Б. Діяльність Народного міністерства внутрішніх справ УНР. С. 91.

12 Центральний державний архів вищих органів влади та управління, м. Київ (далі - ЦДАВО України). Ф. 2241. Оп. 1. Спр. 8. Арк. 36.

${ }^{13}$ Там само. Ф. 1115. Оп. 1. Спр. 24. Арк. 6.

14 Довідник з історії України / Упоряд. та наук. ред. І. 3. Підкова; ред. І. 3. Підкова, Р. М. Шуст; Інститут історичних досліджень Львів. нац. ун-ту ім. Івана Франка. [2. вид., доопрац. і доп.]. К.: Генеза, 2001. С. 954.

${ }^{15}$ ЦДАВО України. Ф. 799. Оп. 1. Спр. 27. Арк. 33.

${ }^{16}$ Там само. Ф. 1115. Оп. 1. Спр. 1. Арк. 20.

${ }^{17}$ В Исполнительном Комитете Киевского окружного о беженцах совещания // Бюллетень Комитета Юго-Западного фронта. 1917. 11 сентября.

${ }^{18}$ ЦДАВО України. Ф. 2241. Оп. 1. Спр. 8. Арк. 37-37зв.

${ }^{19}$ Там само. Ф. 1115. Оп. 1. Спр. 1. Арк. 66-69.

${ }^{20}$ Там само. Ф. 2241. Оп. 1. Спр. 8. Арк. 37.

${ }^{21}$ Там само. Арк. 39.

${ }^{22}$ Там само. Арк. 37.

${ }^{23}$ Там само. Ф. 2241. Оп. 1. Спр. 8. Арк. 37зв.

24 Там само. Арк. 35-35зв.

${ }^{25}$ Там само.

${ }^{26}$ Там само. Арк. 36

${ }^{27}$ Там само.

28 Там само. Арк. 363в.

${ }^{29}$ Хроника // Маленькие одесские новости. 1917. 17 июля.

${ }^{30}$ Перспективы беженцев (из Киевского окружного о беженцах совещания) // Бюллетень Комитета Юго-Западного фронта. 1917. 11 октября.

${ }^{31}$ ЦДАВО України. Ф. 2241. Оп. 1. Спр. 8. Арк. 39.

32 Перспективы беженцев (Из Киевского окружного о беженцах совещания) // Бюллетень Комитета Юго-Западного фронта. 1917. 11 октября.

${ }^{33}$ ЦДАВО України. Ф. 1115. Оп. 1. Спр. 24. Арк. 1-1зв.

${ }^{34}$ Там само. Арк. 2зв.

35 Там само.

${ }^{36}$ Там само. Арк. 5.

37 Там само. Арк. 6.

${ }^{38}$ Історія України від найдавніших часів до сьогодення. Збірник документів і матеріалів / За заг. ред. А. П. Коцур, Н. В. Терес. Київ-Чернівці: Книги ХХІ, 2008. С. 535-536.

${ }^{39}$ ЦДАВО України. Ф. 1115. Оп. 1. Спр. 24. Арк. 5.

40 Там само. Арк. 6.

${ }^{41}$ Там само.

42 Там само. Ф. 2241. Оп. 1. Спр. 8. Арк. 39.

${ }^{43}$ Копиленко О. Л., Копиленко М. Л. Держава і право України 1917-1920 рр.: [навч. посіб.]. К.: Либідь, 1997. С. 26. 